\title{
Spatial and temporal dynamics of Arabian Gulf coral assemblages quantified from remote-sensing and in situ monitoring data
}

\author{
S. J. Purkis ${ }^{1,2, *}$, B. Riegl ${ }^{1}$ \\ ${ }^{1}$ National Coral Reef Institute, Nova Southeastern University Oceanographic Center, 8000 Northern Ocean Drive, \\ Dania, Florida 33004, USA \\ ${ }^{2}$ Institute of Earth and Life Sciences, Vrije Universiteit, De Boelelaan 1085, 1081 HV Amsterdam, The Netherlands
}

\begin{abstract}
We analysed spatial patterns of coral communities mapped from IKONOS satellite imagery in combination with $8 \mathrm{yr}$ of traditional ecological monitoring data and archived sea-surface temperature data to explain why coral assemblages in the SE Arabian Gulf (Jebel Ali, Dubai) are impoverished and most do not build reefal frameworks. Analysis of archive sea-surface temperature (SST) data confirmed that the area is subject to recurrent and cyclic temperature anomalies at a frequency which suggests at least a partial link to the El Niño Southern Oscillation via the Indian Ocean Zonal Mode. Classification of high-resolution (4 m pixel-size) IKONOS satellite data gave a large-scale synoptic overview of substrate zonation which, in tandem with a long-term ecological time-series study, allowed us to determine the spatial and temporal dynamics of the coral community. We show that the spatial expression of 4 coral assemblages, as mapped using the IKONOS imagery, is consistent with what would be predicted if reef development was repeatedly 'reset' on a decadal time-scale following recurring episodes of coral mass mortality induced by severe SST anomalies. Furthermore, merging the remotely sensed map of substrate distribution with a detailed bathymetric digital elevation model, revealed no evidence of any significant framework development in the past, suggesting that the cycle of temperature-induced mortality has been operating for some considerable time.
\end{abstract}

KEY WORDS: Mass mortality $\cdot$ Disturbance $\cdot$ Remote-sensing $\cdot$ Monitoring $\cdot$ Spatial pattern $\cdot$ Coral reef · Arabian Gulf

\section{INTRODUCTION}

Many studies have documented stresses on reefs worldwide with concomitant degradation (Lough 2000, Wilkinson 2000). In the Arabian Gulf, corals have been persisting in probably the most stressful environment for reef-building corals (Kinsman 1964, Downing 1985, Sheppard et al. 1992, Riegl 2001, Sheppard \& Loughland 2002). Additional to annual temperature excursions of up to $20^{\circ} \mathrm{C}$, marine biota in the Arabian Gulf have been affected by several strong sea-surface temperature (SST) anomalies and associated coral bleaching events (1996, 1998, 2002). The 1996 event, which occurred after a relatively long period of apparent stasis, led to coral mass mortality, which was less pronounced in the following events (George \& John 1999, 2000, 2002, Riegl 1999, 2002).

The development of coral communities and reef growth are intricately linked to disturbance frequency. Reef growth needs a long enough period of stability to allow 'catch-up' (van Woesik \& Done 1997, Braithwaite et al. 2000). If a critical disturbance-threshold is exceeded, no reefs can be built, even if the area in question is rich in corals (Riegl 2001). This mechanism, suppression of reef-framework development by frequent disturbance, is of particular importance in highlatitude reef settings and has been extensively studied (Highsmith 1980, Colgan 1990, Eakin 1996, 2001). Also, 
the Arabian Gulf has been intensely studied in this respect and several ancillary studies documenting the biological and geological dynamics of reef building exist for the Arabian Gulf (Shinn 1976, Sheppard et al. 1992, 2000, Sheppard \& Loughland 2002, George \& John 1999, 2000, 2002) and the present study area, Jebel Ali (Riegl 1999, 2001, 2002).

Remote-sensing is a proven tool to quantify spatial extent of shallow benthic habitats (Mumby et al. 1997, Andréfouët et al. 2001, Purkis et al. 2002). Recent studies identified the IKONOS sensor as an appropriate platform to resolve reef facies due to its appropriate spectral and spatial resolution characteristics (Maeder et al. 2002, Mumby \& Edwards 2002, Andréfouët et al. 2003).

A traditional disjunct between remote-sensing and ecological studies is their respective spatial scales. Due to their observer-dependence the spatial extent for individual samples in ecological studies is restricted to the scale of only metres to a few hundred metres (as far as a diver can swim). The wide observational angle of air- or space-borne sensors allows synoptic sampling on scales of a few to hundreds of kilometres. While the integration of results from studies on these 2 scales is desirable (Mumby \& Harborne 1999, Andréfouët \& Payri 2000, Roelfsema et al. 2002), the two nevertheless relatively rarely meet. The aims of this study were to integrate data sets obtained by 2 different approaches and on 2 different scales. It used satellite imagery to quantify facies distribution, and interpretation was facilitated by the use of ecological time-series data collected between 1995 and 2003 on an annual basis. The aim was to determine the spatial and temporal dynamics of the coral communities in the SE Arabian Gulf.

\section{MATERIALS AND METHODS}

Study area. The study site was selected for the availability of ancillary data and is part of an ongoing study. It is situated in the SE Arabian Gulf, about halfway between Abu Dhabi and Dubai, near Jebel Ali, in the United Arab Emirates (Fig. 1).

Both atmospheric and water temperature in the Arabian Gulf exhibit extreme negative and positive temperature excursions for the (sub)tropical biota (coral reefs, tropical seagrasses, mangroves) (see Fig. 2). Negative anomalies occur in winter and are mostly caused by the Shamal, a cold north wind from the Iranian highlands (Murty \& El Sabh 1984). Several authors have attributed coral mortality to the cold temperatures and unusually low tides associated with Shamals (Shinn 1976, Coles \& Fadlallah 1991, Sheppard et al. 1992, Fadlallah et al. 1995). Recently, several anomalously strong positive temperature excursions were observed (George \& John 2000). In 1996, 1998 and 2002, SST

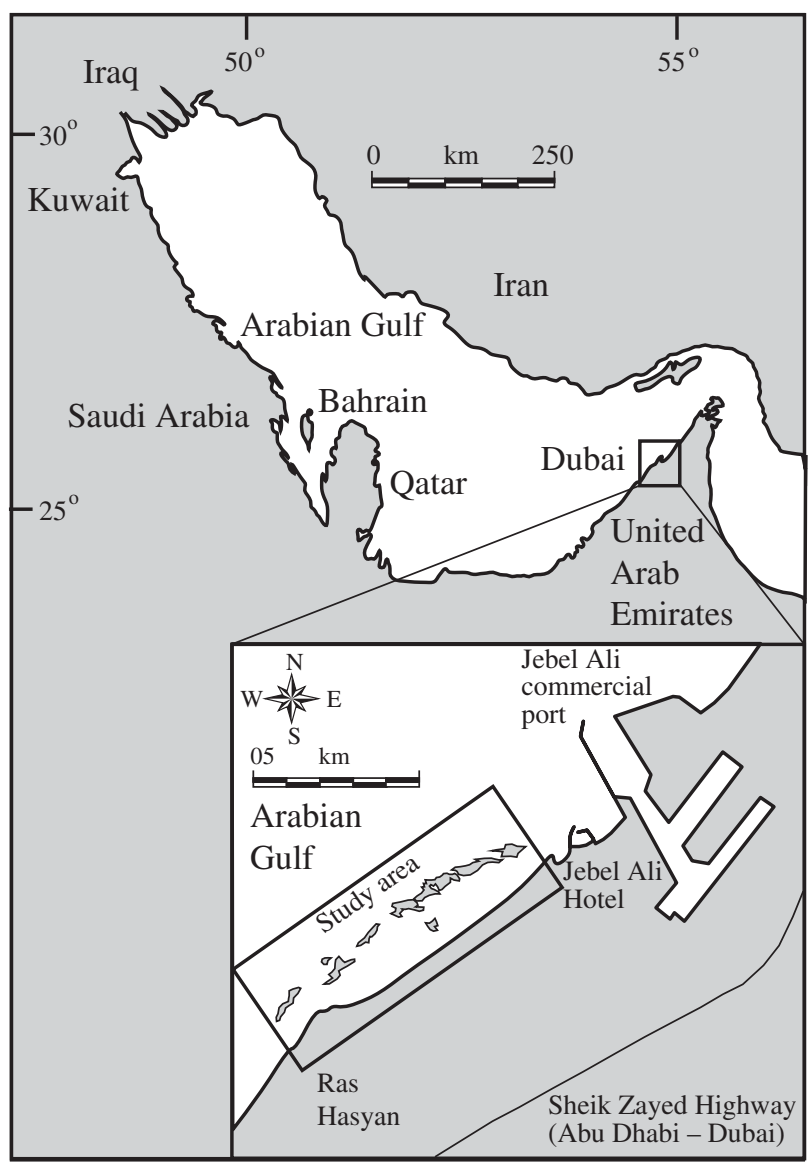

Fig. 1. Study area near Jebel Ali in SE Arabian Gulf

anomalies of +2 to $2.5^{\circ} \mathrm{C}$ above the average summer maximum temperatures measured in situ $\left(33^{\circ} \mathrm{C}\right.$ in July 1994 and 1995, Dubai Municipality) persisted from April to September. Local in situ temperatures maxima attained $35.5^{\circ} \mathrm{C}$ in 1996 and $37^{\circ} \mathrm{C}$ in 2002 (Riegl 2002). It is possible that these strong local excursions are influenced or caused by the Indian Ocean Zonal Mode (Loschnigg \& Webster 2000, Loschnigg et al. 2003) which is connected to the El Niño Southern Oscillations (ENSOs). Nasrallah et al. (2004) linked extreme temperature excursions in the NW Gulf to a northward shift of the Subtropical Jet Stream in summer.

Previous studies (Riegl 1999, 2002, Riegl et al. 2000) identified 5 typical coral assemblages of variable live cover within the study area:

- Assemblage A: Large, widely spaced Porites lutea and other Porites spp. mixed with several other, mainly massive, species. This assemblage was widely distributed on hardgrounds, and suffered only moderately from the SST anomalies.

- Assemblage B: Mainly tabular colonies of Acropora clathrata and A. downingi forming a dense assemblage with high (40 to $90 \%$ ) live cover and fre- 
quently overtopping competitively inferior massive corals, such as Porites spp., Cyphastrea spp. and Platygyra spp. Heavy mortality occurred in 1996 (see Fig. 9F), less in 1998 (most Acropora spp. were already dead).

- Assemblage B1: Dense Assemblage B with less space cover $(<25 \%)$ on edges but still Acropora dominated. Competitively inferior species occupied an important portion of the substratum and had not yet been overtopped.

- Assemblage C: Groups of faviids (notably Platygyra lamellina, P. daedalea, Cyphastrea serailia, Favia spp.), either widely spaced or densely packed.

- Assemblage D: Widely spaced Siderastrea savignyana colonies on sandy hardgrounds.

- Assemblage E: Densely spaced (80\% coral cover) columnar Porites harrisoni colonies, intermingled with massive colonies, mainly faviids (Favia spp., Platygyra spp.) with patchy distribution.

Data acquisition. Sea-surface temperature (SST) was obtained by in situ measurements provided by the Dubai municipality (data at 3 mo intervals for the period 1993 to 1997). Since they were found to correspond with remotely sensed data that gave a more complete record, these in situ data were not further used in the present study. Monthly and weekly averages of SST were obtained from website http://ferret. wrc.noaa.gov/las1/climate_server from the COADS (Comprehensive Ocean Atmosphere Data Set, $2 \times 2^{\circ}$ grid compiled monthly data from ship reports) and NCEP (National Centre for Environmental Prediction, $1 \times 1^{\circ}$ grid combining in situ and satellite data, referred to as Reynolds, SST; Reynolds \& Smith 1994) data sets. Pre-1950 COADS SST data were discarded as they have been deemed of marginal quality (Wang \& Wang 1996, Kestin et al. 1998). The COADS data set was used for the period 1950 to 1993, the Reynolds data set was used from 1993 onwards. The periodicity of SST oscillations was evaluated using a Fast Fourier Transform (FFT) algorithm (Lyons 1997, Ingle \& Proakis 2000). Additional SST anomaly data derived from NOAA AVHRR imagery were obtained from the coral hotspot site (www.nodc.noaa.gov/sog/hotspots) and used to verify temperature excursions observed in the COADS and Reynolds data sets.

For reef-mapping based on remote-sensing 2 types of satellite images were used: $15 \times 15 \mathrm{~m}$ pixelresolution ASTER imagery for site orientation and use as navigational map in hydrographic survey (imported into the survey software Hypack for line selection) and $4 \times 4 \mathrm{~m}$ pixel-resolution IKONOS imagery for optical discrimination of benthic habitats. We selected an IKONOS-2 11-bit multi-spectral satellite image acquired on 2 July 2001 (Scene 75209) at 06:49 h GMT. Sun elevation and nominal collection azimuth at the time of acquisition were 67 and $65^{\circ}$ respectively, the tidal stage was $3 \mathrm{~h}$ after high water, water clarity was high and the surface was calm. The image was unaffected by atmospheric dust and there was no cloud cover. Although the level of geographic accuracy of the raw image was reasonable, further geocorrection was conducted against 40 ground control points acquired using a portable Leica 500 DGPS (global positioning system) with a horizontal accuracy of $\pm 30 \mathrm{~cm}$, yielding an average root mean square (RMS) error of 0.66 pixel or $2.65 \mathrm{~m}$.

Optical ground-truth. Optical ground-truthing was conducted in situ during the period 5 October to 10 November 2002 using a suite of intercalibrated optical tools to measure the spectral properties of the dominant substrate types within the study area: A PhotoResearch PR650 spectroradiometer was used to quantify remote-sensing reflectance just above the water/ air boundary $\left[R_{r s}(z=a)\right]$ immediately above the water surface in accordance with the protocols described by Pasterkamp et al. (2003), and an OceanOptics SD2000 fibre-optic spectrometer measured the signal proportional to substrate reflectance $\left(R_{b}\right)$ beneath the water surface and in close proximity to the seabed, as described by Purkis \& Pasterkamp (2004). To parameterise the optical status of the water column and atmosphere we used a Biospherical Instruments PRR600 profiling reflectance radiometer linked to a PRR610 surface reference sensor to simultaneously measure the attenuation of light in the water body $(k)$ and the downwelling irradiance in air $\left(E_{a d}\right)$, and a Microtops sunphotometer to quantify total atmospheric aerosol optical thickness at $550 \mathrm{~nm}\left(A O T_{550}\right)$.

The time-lag between optical field campaign and image acquisition has implications for the values of $k$ and $R_{W}$ (the reflectance of optically deep water) which, being apparent optical properties, vary with space and time. This precludes the direct implementation of the optical equation as used by Purkis \& Pasterkamp (2004). The imagery and in situ optics were related over a deep water-reflectance target (position constrained by DGPS), which was visited daily at local times appropriate to ensure that solar geometry was comparable with that at image acquisition. In rapid succession, $k$ and $R_{r S}(z=a)$ were evaluated using the PRR-600 profiler and PR650, respectively. Using this data, a look-up table of $R_{r s}(z=a)$ versus $k$ was constructed for a number of sea conditions. A match was subsequently sought between satellite and PR650 values of $R_{r s}(z=a)$, with the result that in situ data acquired on 29 October 2002 provided a match with an absolute error in reflectance of $0.10,0.16$ and $0.13 \%$ for Bands 1, 2 and 3, respectively. The associated $k$ and $R_{W}$ spectra, evaluated directly following the PR650 measurement were resampled to the bandwidths and 
sensitivity of the IKONOS sensor and used as input to the optical equation. Implicit to this approach is the assumption that (1) the interplay between absorption and scattering governing the observed reflectance of the water column is relatively consistent; (2) the optical properties of the water column are homogeneous over the study area. The lack of fluvial input into the area and personal experience leads us to believe that the initial assumption is reasonable. Observations made during this and previous campaigns in the area reveal that the dominant cause of water turbidity is high sediment loading caused by the suspension of unconsolidated sand during storm events. This being the case, suspended particulates are the dominant parameter influencing both $R_{r S}(z=a)$ and $k$. Both the in situ optical measurements and image acquisition coincided with extensive calm periods and high water clarity, the sun elevation for both in situ and satellite acquisition was constant $\left( \pm 65^{\circ}\right)$, as was the observation angle of the IKONOS and PR650 ( $\pm 25^{\circ}$ off nadir). It is reasonable to assume that the excellent match between PR650 and satellite-evaluated reflectance (average deviation for Bands 1 to 3 is $<0.15 \%$ ), will be accompanied by a robust match in $k$. Also, considering the limited size of the study area and the fact that sediment plumes are clearly absent from the imagery, it is not unreasonable to assume that the optical properties of the water body were likely to be relatively homogeneous at the time of image acquisition.

Sufficient spectral data were obtained through ground-truthing using the above-mentioned instruments to allow discrimination of the same classes as those identified by the ecological surveys of the previous 7 yr. Due to the limitation imposed by pixel size, the original 6 coral assemblage classes were simplified into 4 broad categories:

- Live coral corresponding to Assemblages A, C and E.

- Dead dense Acropora spp. corresponding to Assemblage B.

- Sparse coral corresponding to the sparse Subassemblage B1 and, where applicable, sparse portions of Assemblages A, C and E.

- Assemblage D was merged into the more general category 'hardground'.

Besides these 4 coral assemblages, 5 additional substratum classes were encountered (bare carbonate sand, bare hardground, seagrasses (Halodule uninervis with occasional $H$. ovalis), shallow-benthic algal mats (mainly Rhizoclonium tortuosum, Chaetomorpha gracilis and Cladophora coelothrix) and deep macro-algae (typical assemblage comprises Sargassum binderi, $S$. decurrens, Avrainvillea amedelpha and Padina spp.). These are not treated further in this paper, since we wished to concentrate on coral dynamics.
Acoustic ground-truth. A $15 \mathrm{~m}$ survey vessel equipped with a differentially corrected Fugro SeaSTAR 3200LR12 global positioning system (DGPS) was used as a platform for the acoustic survey. The differential correction of the positioning data was conducted in real-time against the Omnistar network of satellites with a horizontal accuracy of $\pm 50 \mathrm{~cm}$, facilitating exact overview of the vessel's position in relation to the satellite imagery, which was loaded into the moving-map softwares Fugawi and Hypack on a lap-top computer. In order to provide data for the digital elevation model (DEM), 3 independent acoustic bathymetry surveys were conducted over the area covered by the IKONOS satellite image; 2 surveys (conducted with 50 and $200 \mathrm{kHz}$ signals on a $10 \mathrm{~Hz}$ sampling frequency provided by a Suzuki 5200 depth-sounder using a post-processed QTCView5 bottom-picking algorithm) covered the entire area. Furthermore, an additional high-resolution survey in the near-shore area, provided detailed bathymetry at a $10 \mathrm{~m}$ line-spacing. All bathymetric data were post-processed and corrected against in situ tidal measurements (Van Essen DI-240 tidal logger) to yield data corrected to a common datum. The merged bathymetry data was interpolated to a regular grid of a size equal to that of the pixel elements of the IKONOS image $(4 \times 4 \mathrm{~m})$ using triangle-based linear interpolation implemented by Code written in Matlab 6.1, yielding a single depth value per satellite pixel.

Image-processing. The IKONOS imagery was radiometrically calibrated using the coefficients of Peterson (2001) to yield pixel values of radiance (W $\mathrm{m}^{-1} \mathrm{sr}^{-1} \mu \mathrm{m}^{-1}$ ) and further corrected for the effect of atmospheric path radiance using the procedure adopted by Schott et al. (1988) and Lenney et al. (1996) to recover values of apparent surface reflectance (\%). The first 3 bands of the imagery (blue, green and red) were subsequently processed to remove the spectral effect of the intervening water column using the procedure of Purkis \& Pasterkamp (2004), resulting in pixel values presumed to be equivalent to substrate reflectance (\%). The thickness of the water column within each pixel of IKONOS imagery is required for this procedure and was derived from the bathymetric digital elevation model (DEM) constructed from the in situ acoustic survey. Each IKONOS image pixel was assigned to 1 of 8 substrate classes using a classifier trained solely using the in situ optical measurements of substrate reflectance. The classification was implemented using the multivariate-normal probability density function described by Purkis \& Pasterkamp (2004). The resulting classified image, which can be considered as a predictive map of benthic habitat distribution, was smoothed using a median filter constructed using a $3 \times 3$ pixel 
neighbourhood to reduce the number of isolated erroneously classified pixels resulting from image noise (Wilson 1992, Lillesand \& Kiefer 1994, Mumby \& Edwards 2002).

Spatial statistics. Since we wanted to express the spatial relationships of the observed seafloor classes quantitatively, we developed an algorithm in Matlab
6.1 that evaluated class-membership of pixels surrounding each other in a selected region of interest. The class-membership of the 8 connected neighbours of each pixel (i.e. only those touching the sides and corners of the seed pixel) was tabulated. Pixel classes were those derived from the classification of the image (see last subsection). It was thus possible to evaluate
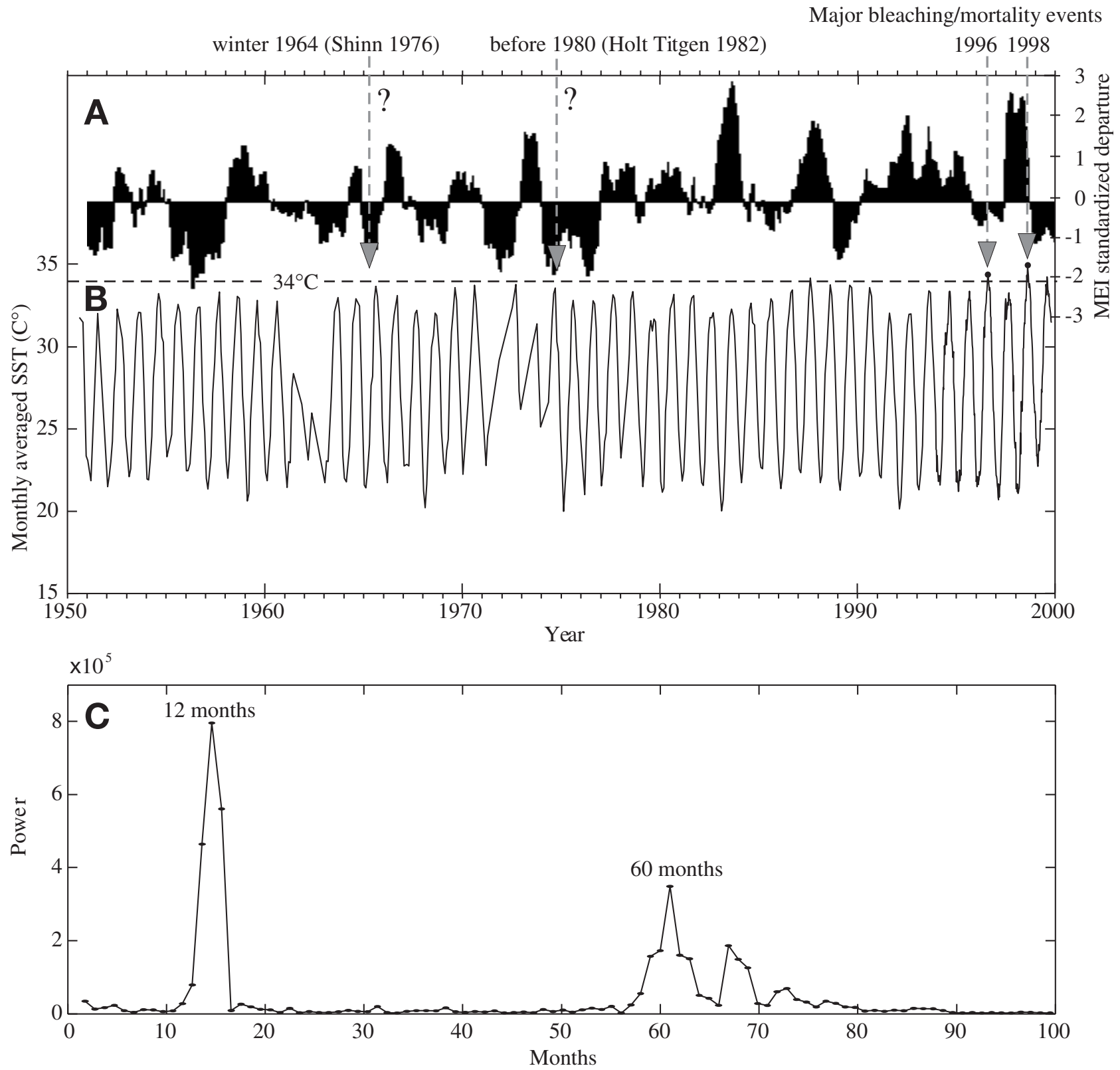

Fig. 2. (A) Multivariate ENSO index (MEI) for period 1950 to 2000 (Wolter \& Timlin 1993, 1998). Negative MEI values represent cold ENSO phase (La Niña), positive values warm ENSO phase (El Niño). (B) Combined sea-surface temperature (SST) data sets for study region (centre point for grid calculation $25.5^{\circ} \mathrm{N}, 54.0^{\circ} \mathrm{E}$ ). For (A) and (B) between 1950 and 15 December 1993 , data are $2 \times 2^{\circ}$ gridded monthly COADS (Comprehensive Ocean Atmosphere Data set), from 21 December 1993, data are weekly $1 \times 1^{\circ}$ gridded Reynold's SST data from NCEP (National Centre for Environmental Prediction) data set; broken vertical lines in (A) indicate periods where SST exceeded $34^{\circ} \mathrm{C}$ and correspond to documented instances of temperature-induced coral mortality. (C) Spectral analysis of temperature oscillations between 1950 and 1999 by Fast Fourier Transform; annual frequency signal is the first strong peak at $12 \mathrm{mo}$; a second clear signal is visible at $60 \mathrm{mo}$ and represents a 5 yr cycle of temperature extremes 
which pixel classes, encoding seafloor classes, were most frequently adjacent to each other. This information is important for our discussion of spatial dynamics in the coral community.

\section{RESULTS}

Spectral analysis of an SST data set from 1950 to 1999 indicated a dominant annual signal reflecting the seasonal temperature oscillation and a 60 mo signal, which indicates recurrent temperature extremes on a roughly $5 \mathrm{yr}$ recurrence interval. Addition of data from the multivariate ENSO index (MEI) (Wolter \& Timlin 1993, 1998, MEI, Climate Diagnostics Center 1998: www.cdc.noaa.gov/people/klaus.wolter/MEI/mei.html) suggested a link between positive SST anomalies in the Gulf with ENSO status in the Pacific (Fig. 2). This suggested link is only based on observations and we are not claiming a proven causality.

Quantitative results of image classification are shown in Fig. 3 \& Table 1. Accuracy assessment was per-

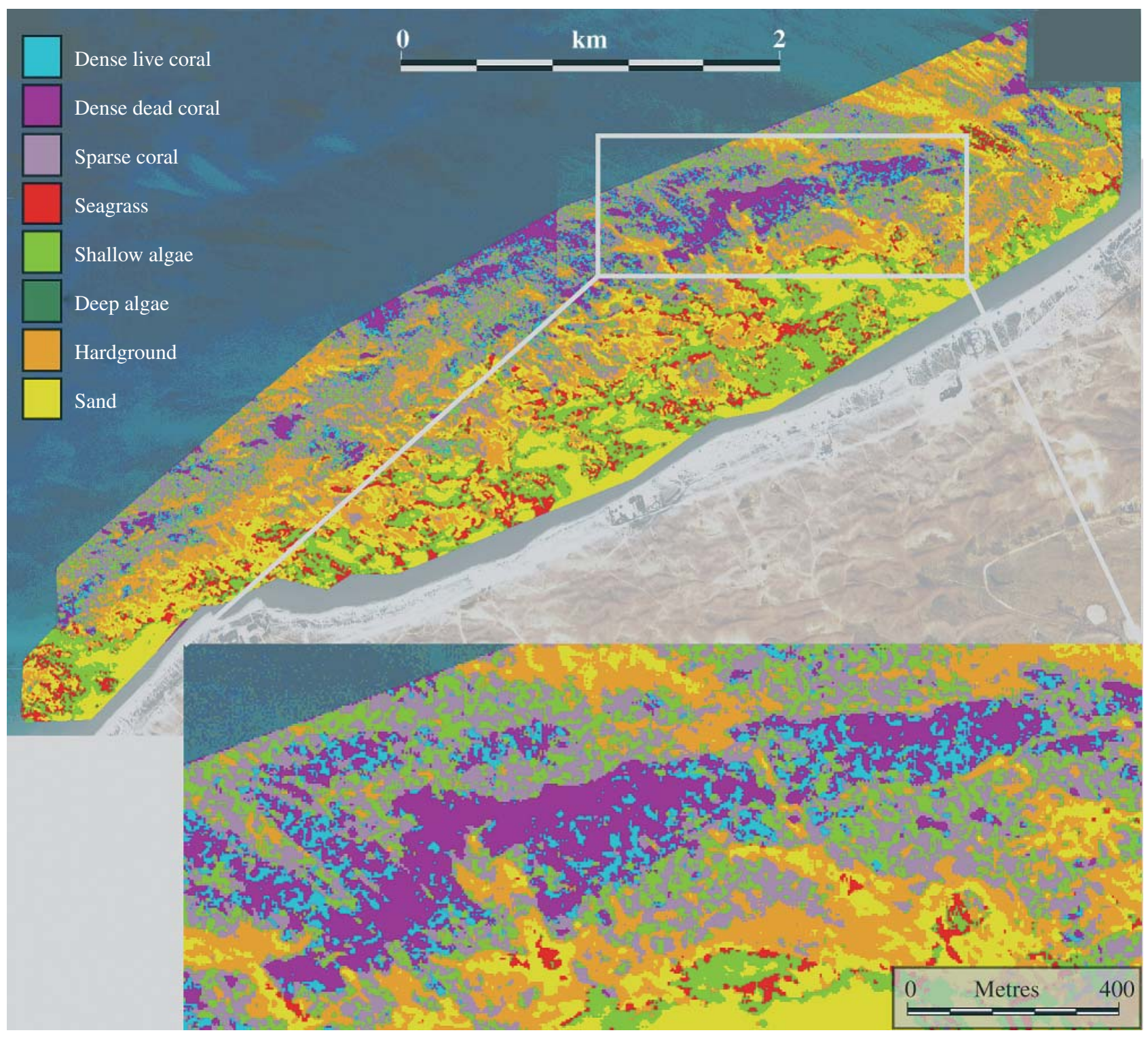

Fig. 3. Classification of IKONOS multispectral image; pixel size is $4 \times 4 \mathrm{~m}$. Inset: Spatial expression of ecological dynamics and disturbance frequency. Dense live coral: assemblage of sparse Acropora spp. (dead at time of image acquisition) mixed with dense carpet comprising mostly small faviid and Porites spp. colonies; dense coral: assemblage of dense and interlocking growths of Acropora spp. (dead at the time of image acquisition); Sparse coral: assemblage of large but sparse live corals (mostly Porites spp.) on hardground; Hardground: assemblage of widely spaced Siderastrea savignyana colonies on sandy hardgrounds. Quantitative expression of this image (i.e. statistics of adjacent pixel classes) are given in Fig. 6 


\section{Ground-truth data}

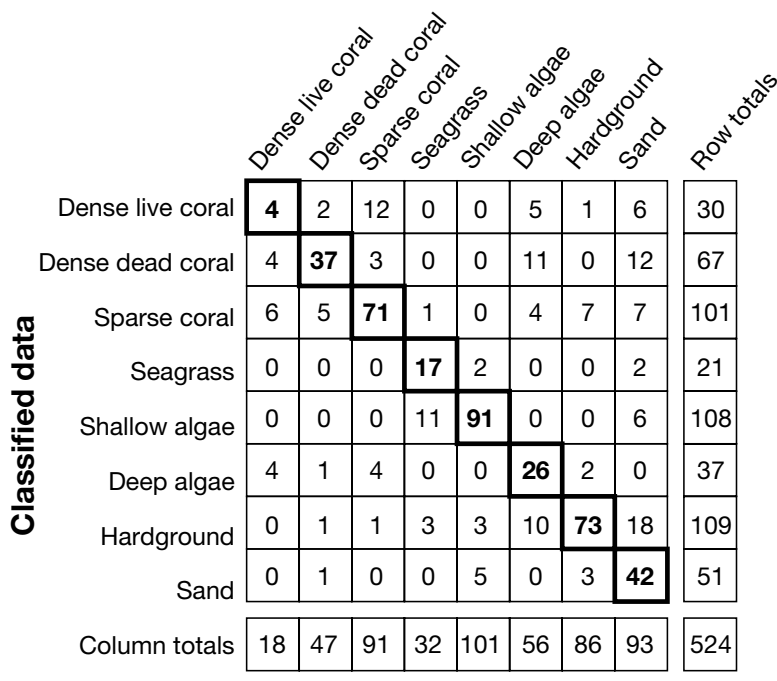

$\mathrm{P}_{\mathrm{O}}=69 \%$ (95\% confidence intervals of $\mathrm{P}_{\mathrm{O}}$ are 73 to $\left.65 \%\right)$ $\tau=65 \%$ (95\% confidence intervals of $\tau$ are 69 to $61 \%$ )

Table 1. Error matrix calculated for classified imagery. Groundtruth pixels that are classified as correct substrate classes are located along major diagonal of matrix, while all nondiagonal elements represent errors of omission or commission. Overall accuracy $\left(\mathrm{P}_{\mathrm{o}}\right)$ and tau coefficient $(\tau)$ are also provided formed against ground-truthing transects and spot checks (524 validation points) conducted using SCUBA and gave an overall accuracy $\left(\mathrm{P}_{\mathrm{o}}\right)$ of $69 \%$ and a tau coefficient $(\tau)$ (Ma \& Redmond 1995) of $65 \%$. It should be noted that the accuracy assessment is likely to be pessimistically biased since the transect data were selected to span heterogeneous areas of the seafloor in an effort to capture and quantify classification errors at patch boundaries. Therefore, the accuracy of $69 \%$ can be considered a true worst-case $69 \%$. If accuracy is assessed against only the spot-check points (which were collected without any a priori knowledge of substrate distribution and are therefore more likely to fall within homogeneous patches) an accuracy of $81 \%$ is achieved $(\tau=77 \%)$.

The classified IKONOS imagery draped over the DEM is shown in Fig. 4. The 3-dimensional image shows a first-order trend of shore-parallel zonation that can be partitioned into 3 rough zones: (1) a zone without coral growth, dominated by sand, seagrass and algae in the first $500 \mathrm{~m}$ from shore; (2) a middle zone consisting mainly of sand and hardground from 500 to 1000 m offshore; (3) a deep zone characterised by coral growth of variable density, interspersed by dense algal growth.

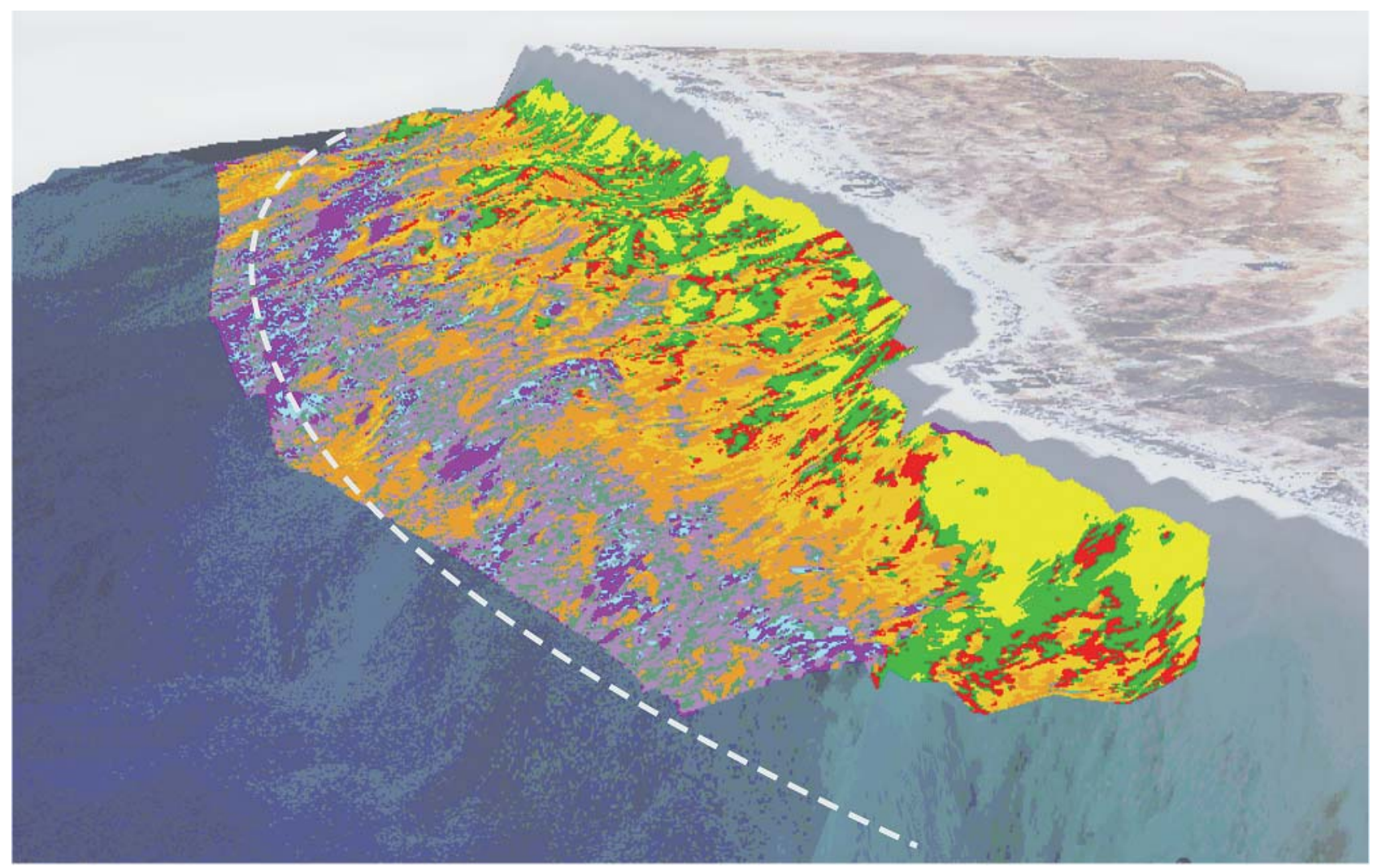

Fig. 4. Digital elevation model of Jebel Ali submarine study area based on combination of acoustic bathymetry survey and image classification trained through in situ hyperspectral optical measurements of substrate reflectance. Broken line marks approximate position of $6 \mathrm{~m}$ isobath. Vertical (depth) scale has been exaggerated by a factor of 500 to resolve geomorphological features of low-relief 


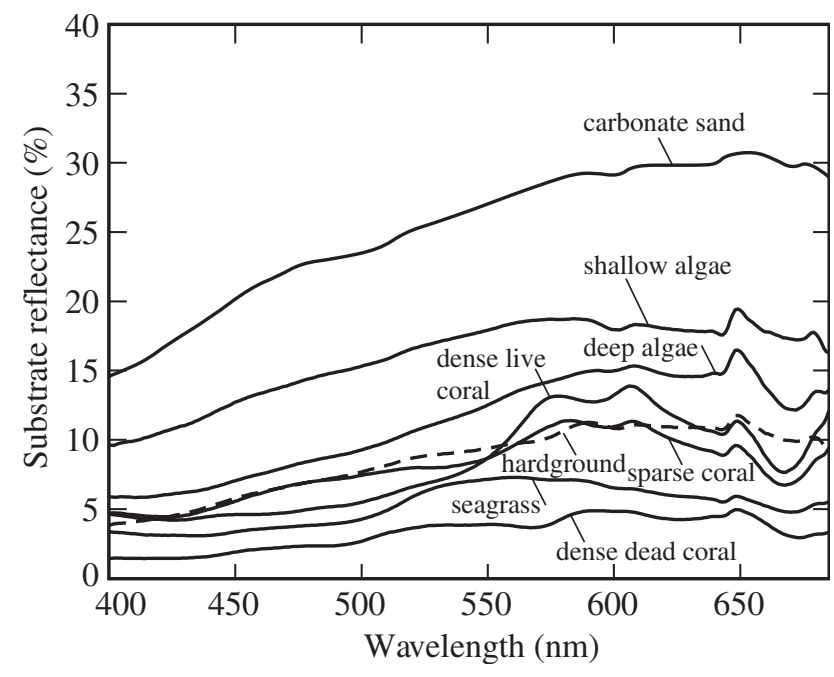

Fig. 5. Representative substrate reflectance spectra evaluated beneath water surface and in close proximity $(0.1 \mathrm{~m}$ elevation) to seabed, obtained from the 8 predetermined substrate classes used for training classification algorithm. The 4 coral assemblages dense live, sparse, dense dead and hardground are coded cyan, light and dark purple and orange, respectively, on classified image in Fig. 3

The ecological data suggested that 4 coral assemblages were resolved on the image (1) an assemblage of large, but sparse corals (mostly Porites spp.) on hardground. These corals were mostly alive at the time of image acquisition; (2) an assemblage of sparse Acropora spp. mixed with faviids and Porites spp. The Acropora spp. were mostly dead at the time of image acquisition; (3) an assemblage of entirely dense and interlocking growths of Acropora spp. which were all dead at the time of image acquisition; (4) an assemblage of very sparse, small Siderastrea savignyana colonies on sandy hardgrounds. Spectra for these 4 and the remaining 4 additional substratum classes are shown in Fig. 5.

A patchy distribution in these 4 classes is evident. Their patchiness is quantified by Purkis (2004), who compared patch-size to patch-frequency, revealing that patch-size is inversely related to patch-frequency and that the relationship follows a power-law over several orders of magnitude, which for the majority of substrate types can be considered fractal in nature. Coral assemblages show a 'halo'-like structure, whereby patches of dense dead coral are surrounded by sparse live coral and finally by hardground with only occasional corals (Fig. 6; see also Fig. 9). This 'halo' effect is quantified in Fig. 6, which shows dense coral pixels (Acropora spp. thickets killed during the 1996 positive SST anomaly) mostly in contact with dense, live coral pixels; in turn, these are mostly in contact with sparse live coral pixels, which are mostly in contact with hardground pixels, which are mostly in contact with sand pixels.

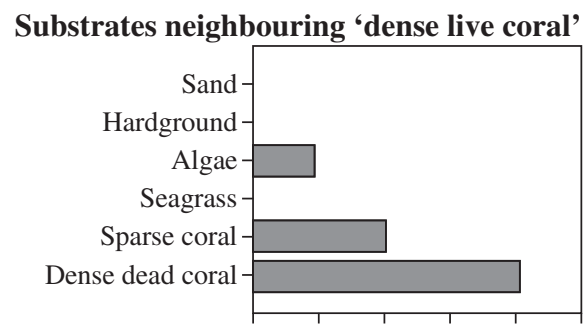

Substrates neighbouring 'dense dead coral'

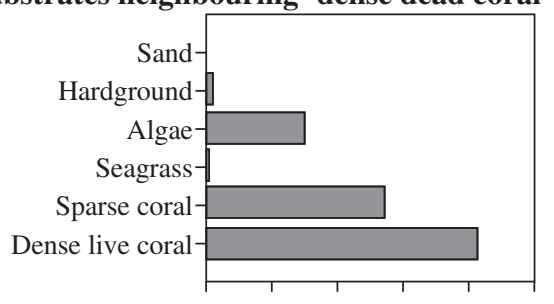

Substrates neighbouring 'sparse coral'

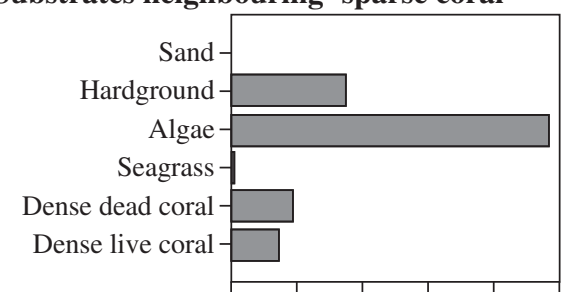

Substrates neighbouring 'hardground'
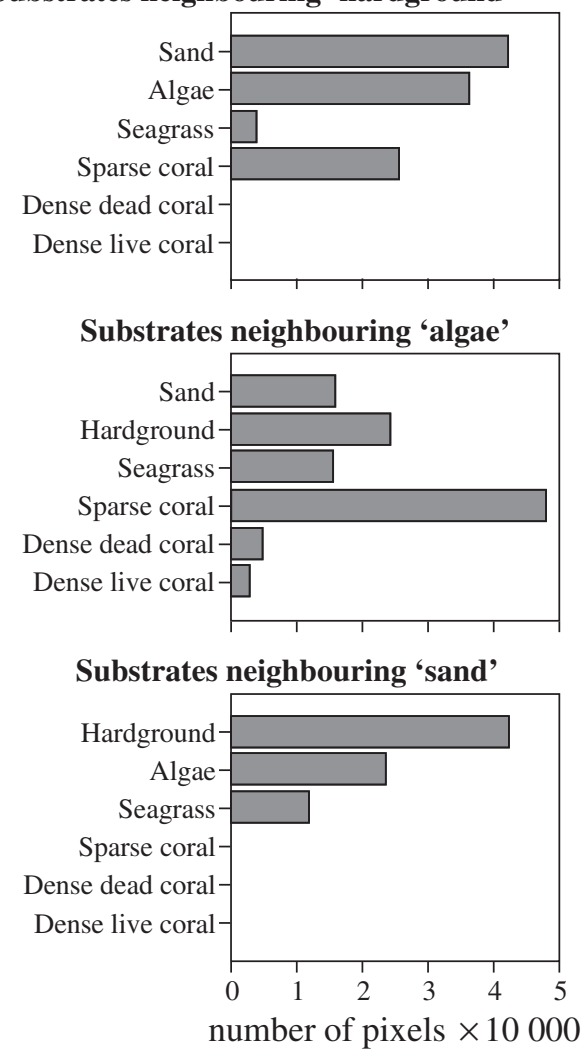

Fig. 6. Spatial relationships of pixel classes. Bar-charts show frequency of adjacent pixel classes. Only those pixel classes important for discussion in text are shown 


\section{DISCUSSION}

This study provided us with an opportunity to integrate remotely sensed map information with ecological monitoring data. The marriage of these intrinsically different data products enhanced the value of both approaches. It allowed us to lift the remote-sensing above a pure mapping exercise and added a badly needed quantitative spatial component to the ecological data set.

In this paper, we use a conceptual derivation of Walther's law of succession ('conformable superpositional contacts occur only between laterally adjacent facies') to link the lateral facies patterns obtained from the remote-sensing map and the ecological time-series (Fig. 7). Essentially we consider the ecological timeseries as a stratigraphic column with conformable superpositional contacts that can then be projected into the lateral facies. Riegl \& Piller (2000) used a similar approach for actualistic reconstruction of a middle Miocene stratigraphic column with the help of a facies map of the Jebel Ali area.

The sequence of coral community development, as derived from ecological time-series data and spatial analyses obtained in the period from 1995 to 2003 (Riegl 1999, 2002) is illustrated in Figs. 8 \& 9. The occurrence of any coral assemblage in the greater study area is tied to the availability of cemented hardgrounds. These are formed by precipitation from the water column of calcium carbonate cements that col-

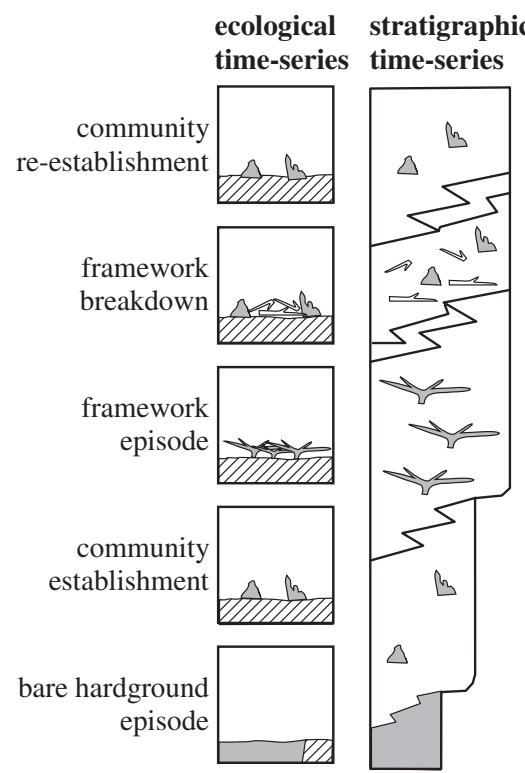

Adaption of Walther's Law of facies succession

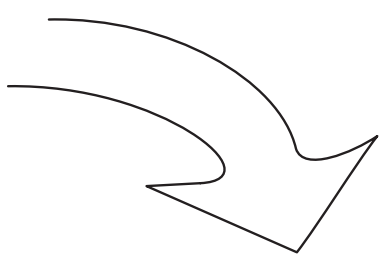

late the sand grains (Shinn 1969). The edges of these hardgrounds are frequently covered by mobile sand sheets of a few centimetres thickness, while the central parts usually are free of such sediment. Therefore, we assume that the more central areas of hardgrounds are a better substratum for the settlement of coral larvae. Although moving sand does not necessarily preclude Acropora spp. from settling and persisting in an area (many lagoonal species with open arborescent growth form, such as the Atlantic A. cervicornis or the Indo-Pacific A. formosa, A. microphthalma, A. teres and some others, are very successful in such sandy environments), the corymbose to tabular species of the Arabian Gulf (A. clathrata, A. downingi, A pharaonis, A. arabensis) belong to that group of Acropora which throughout their range prefer an environment without permanent, deep sand cover. If corals settle close to the edges of the hardgrounds, they are subject to greater loads of resuspended sediment during rough seas. Because of the high energetic cost associated with clearing sediment from coral tissue (Riegl \& Branch 1995), those at the peripheries of hardground patches are at a greater physiological disadvantage than their kin in the centre of the patches. As a consequence of preferential settlement and larval survival as well as lower energetic cost of cleaning tissues of sediment, dense assemblages of small corals develop preferentially in the best-suited environments, which are usually a distance from the edges of the hardground patches. Furthermore, Acropora spp., despite their branching morphology and demonstrated capability to remove sediment (Riegl et al. 1996), are relatively sensitive to sedimentation stress (Kendall et al. 1985). Therefore they tend to be found in areas where the least sediment can be resuspended during storms and resettle on the corals, i.e. the centres of the hardground patches. As corals grow, the faster-growing and more aggressive Acropora spp. begin to monopolise space by overshadowing slower-growing poritids, faviids and siderastreids (Shinn 1976, Riegl 2001, 2002), forming a dense, interlocking biostromal framework (coral carpet sensu stricto Riegl \& Piller 2000). As a climax is approached in this assemblage, dense mono-

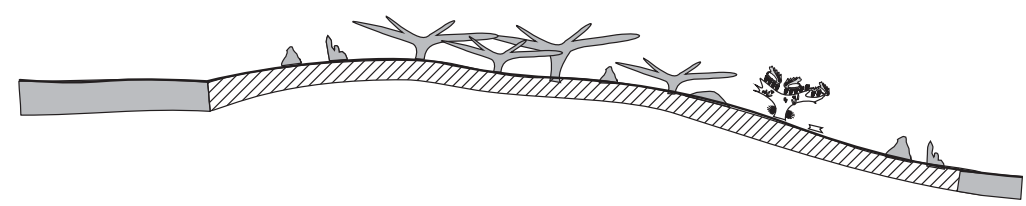

Fig. 7. Conceptual derivation of Walther's law to link lateral facies patterns obtained from remotesensing map and ecological 
(1) Recruitment onto hardground

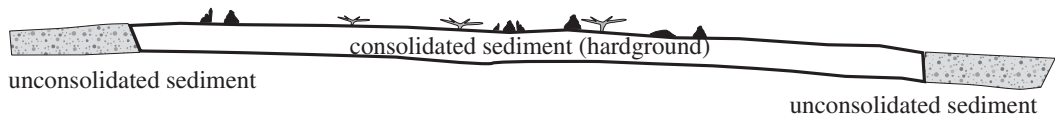

(2) Establishment of community

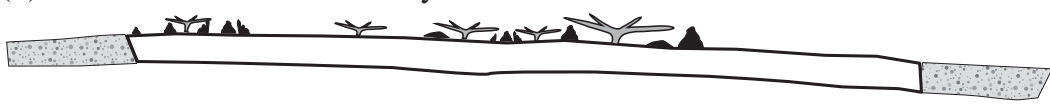

(3) Climax stage with competitive displacement of weaker species

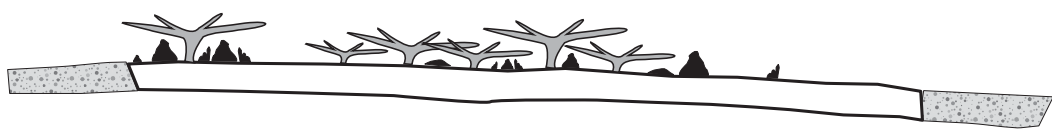

(4) Bleaching and selective, compensatory mortality

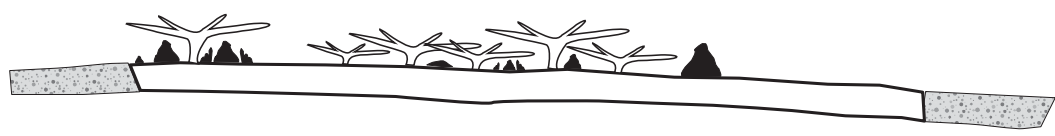

(5) Framework breakdown and new recruitment

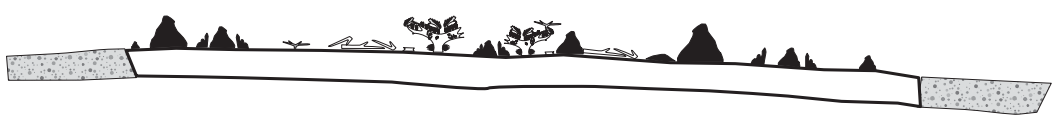

(6) Re-establishment of community and lateral spread

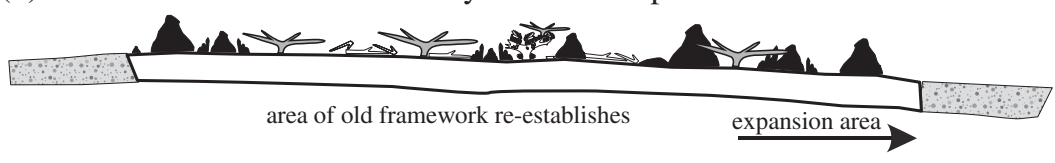

Fig. 8. Ecological dynamics of studied reef coral assemblages. 1: Corals settle on hardground. 2: In the centres of the hardground patches, where conditions are most favourable, they grow eventually to dense stands, dominated by fast growing Acropora spp. (grey). 3, 4: Episodic environmental disturbances kill preferentially the dominant space competitor, Acropora spp. (grey corals turn white), while the slower growing, but more resilient faviids and poritids survive (black). 5, 6: The Acropora spp. framework rapidly breaks down due to high rates of bioerosion, and a new Acropora generation thus 'settle' on the original hardground, not on the dead, still-standing skeletons of the previous generation. Thus, no reef is formed and the community remains non-framebuilding or, at best, biostromal specific patches of Acropora develop in the centres of hardgrounds (Riegl 1999, 2002). These dense patches are of finite size (ultimately determined as a function of growth rate versus disturbance frequency) but actively expand laterally. In their peripheral areas, space cover by Acropora spp. is lower and species distribution within the assemblage is more equitable (i.e. a climax is not yet reached). The substratum is less suitable towards the edges of the hardground patches (more sand moving over the hardground) and consequently recruitment is lower, with resulting lower density corals consisting of more sediment-tolerant species (poritids, faviids and siderastreids rather than acroporids and pocilloporids).

The direct spatial expression of this ecological succession is reflected in the lateral component of the observed facies pattern. The overall coral area is clearly characterised by a stacked pattern of differentdensity coral growth. Dense acroporid growth of $>50$ to $100 \%$ substratum cover by corals (dead at the time of image acquisition and groundtruth, coloured dark purple) is surrounded by growth of less dense corals with $25 \%$ to a maximum of $50 \%$ substratum cover (cyan in Fig. 3, alive at the time of image acquisition and ground-truth), which then grades into areas of sparse corals (mostly dead at the time of image acquisition and ground-truth, light purple in Fig. 3) and then into almost bare hardground (orange in Fig. 3).

The succession from bare substratum to dense biostromal coral framework,

Fig. 9. Ecological dynamics of studied coral assemblages between Ras Hasyan and Jebel Ali. (A) First stage of community development, marked by small colonies recruiting onto hardground; illustrated are poritids, siderastreids and faviids; this community stage is also found at periphery of hardgrounds. (B) Expanding space cover by pioneering community; illustrated is Porites lutea. (C) Increasing density of coral growth, Acropora spp. begins to overgrow weaker competitors. (D) As community moves towards climax stage, slower-growing species and weaker competitors are increasingly confined to peripheries of dense coral patches; illustrated is interface between dense Acropora downingi growth and sparse Porites lutea community. (E) Climax community in dense Acropora spp. patches. Acropora have formed a dense canopy that overshadows most other corals and totally monopolises space. (F) Sea-surface temperature anomalies cause mass mortality of dominant Acropora spp.; other coral taxa suffer far less; these are compensatory mortality events, disadvantaging the most aggressive species and thus assuring maintenance of weaker competitors in the system (Connell 1978). (G) Breakdown of coral framework is rapid; complete breakdown takes 10 to 15 yr, but already after $5 \mathrm{yr}$, the overall integrity of the framework is lost and many colonies have started to collapse. (H) Recruitment into denuded areas is relatively slow since, due to the mass mortality, few colonies are available as larval sources 


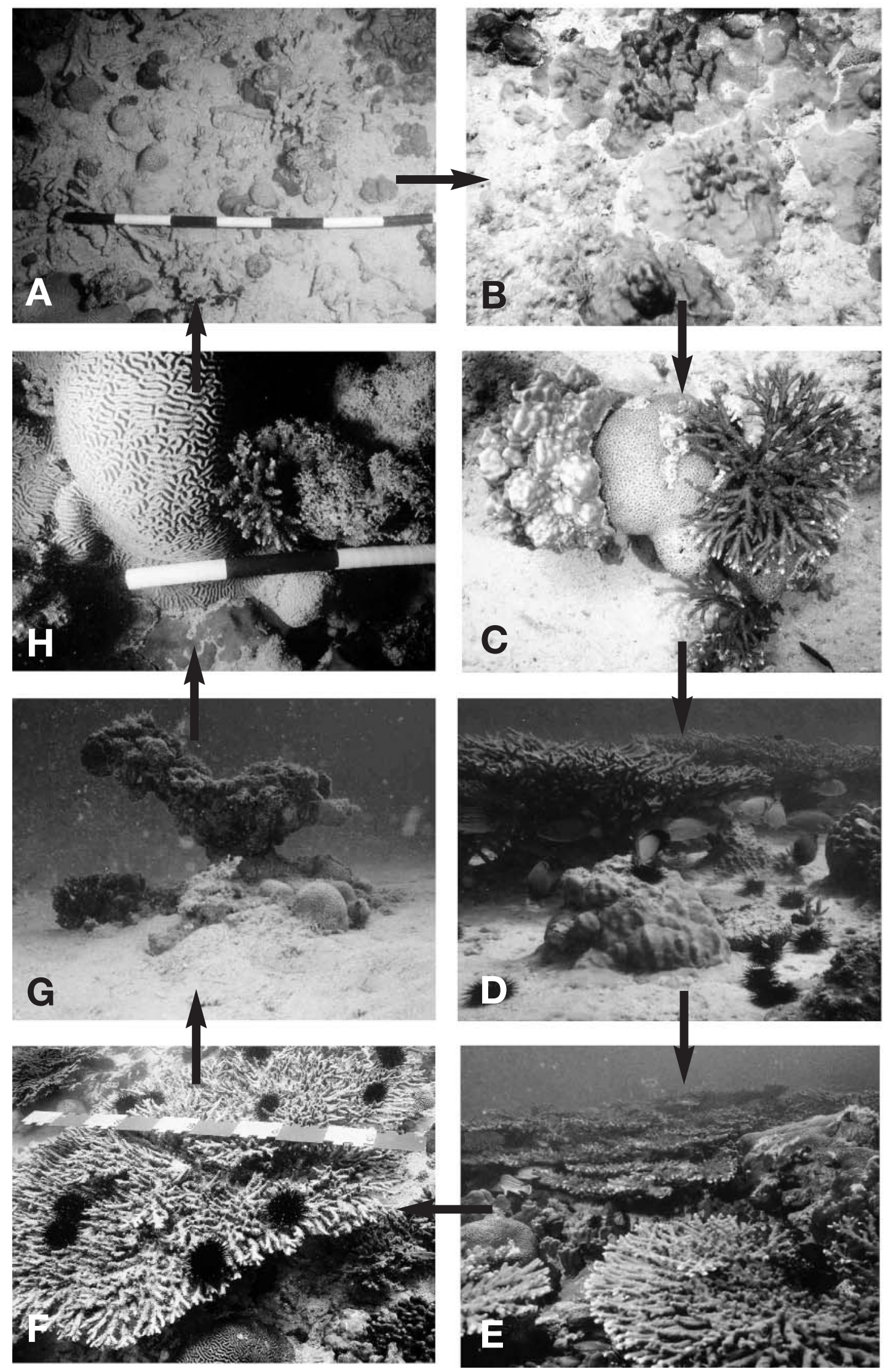


observed both in the ecological and remotely sensed imagery data sets, also codes disturbance. Sea level in the Arabian Gulf has been near the present level for about 2000 yr (Lambeck 1996) and has therefore provided corals with a stable bathymetric environment. Exhibiting a growth rate of approximately $10 \mathrm{~cm} \mathrm{yr}^{-1}$ (Shinn 1976, Coles \& Fadlallah 1991), Arabian Gulf Acropora spp. grow about 10 to 20 times faster than the common massive corals, which display growth rates typically in the order of 0.4 to $1.2 \mathrm{~cm} \mathrm{yr}^{-1}$ (Hubbard \& Scaturo 1985). With such a disparity in growth potential, it could be expected that, if growth remained largely unchecked, acroporids would soon dominate most of the available hardground. Individual massive corals would certainly persist, partly because the dense Acropora spp. thickets would also provide suitable habitat for other species, however, dominance would clearly be skewed towards Acropora spp. Once all hardground was occupied, upward framework growth should have ensued due to new corals using the skeletons of previous generations as substratum. However, neither were all hardgrounds covered by corals (in fact $42.3 \%$ of hardground was bare, $32.4 \%$ was covered only by sparse coral growth, $25.2 \%$ by algae and $14 \%$ by dead, dense corals), nor was any biohermal reef growth observable. The digital elevation model (Fig. 4) and field observations clearly show that the corals simply drape over underlying morphology and do not build a 3-dimensional framework. Riegl (2001) suggested that repeated disturbances, mediated by SST anomalies triggering coral mass mortality, suppress the development of typical catch-up-type reef growth (Neumann \& Macintyre 1985). The present study shows the lateral spatial expression of this theory, namely incipient but obsolete frameworks surrounded by sparse coral growth that never approached the framebuilding stage.

The bleaching events of 1996, 1998 and 2002 correspond to periods in which SST exceeded $34^{\circ} \mathrm{C}$ (Fig. 2), surpassing the thermal tolerances of corals and resulting in bleaching and/or mass mortality (primarily of acroporid corals) in the study area, as documented by Riegl (2002). Fig. 2 also shows 1987 as an unusually hot year. It is unknown whether any bleaching occurred in this year in the Arabian Gulf; however, 1987 was a bleaching year in some parts of the Indian Ocean (Hoegh-Guldberg 1999).

The spectral analysis (FFT) of SST records covering half a century supported previous speculations regarding recurrent coral mass mortality events in the SE Arabian Gulf (Riegl 1999, 2002) by showing that indeed a 5 yr mode of higher-than-usual SST is observed. This frequency is lower than the periodicity of the ENSO, which typically displays a robust 4 yr period (Philander 1990, Wang \& Wang 1996, Eccles \&
Tziperman 2004) but with events occurring at intervals of 2 to $7 \mathrm{yr}$ (Fiedler 2002). Indeed, the multivariate ENSO index (Wolter Timlin 1993, 1998) recognised 13 El Niño warmings in the period 1950 to 1998, averaging a period of $3.6 \mathrm{yr}$ (Spencer et al. 2000). Coral mortality resulting from exceptionally warm sea-surface temperatures during El Niño periods is widely documented (Glynn 1991, 1993, Aronson et al. 2000, Wilkinson 2000) and the recurrence interval of temperature-mediated coral bleaching is typically greater than 3 to $5 \mathrm{yr}$ (Wellington et al. 2001). Comparison of the frequency content of Arabian Gulf SST data (Fig. 2) with the multivariate ENSO index might suggest that temperature extremes in the Gulf may be, at least partly, correlated with ENSO, which drives the periodicity of the Indian Ocean Zonal Mode (IOZM: Loschnigg \& Webster 2000, Loschnigg et al. 2003). The 1998 bleaching events corresponded to a strong warm ENSO (El Niño) event, whereas the 1996 bleaching clearly occurred at the time of an elevated SST that did not correspond to a warm ENSO event. In fact, the MEI standardised departure is negative, indicating a cold ENSO (La Niña) period in the Pacific at this time. During the La Niña, however, when temperatures in the eastern Indian Ocean are low, the IOZM brings high temperatures to the NW Indian Ocean. The strong heating in the Arabian Gulf region in 1996 could therefore have been an expression of the strong ENSO cooling around Indonesia (for effects on corals there, see van Woesik 2004). The strong heating again in 1998 could have been an expression of the extraordinary strength of the 1998 ENSO event, which overrode the IOZM (Loschnigg et al. 2003) and again caused coral bleaching in the Arabian region.

While the spectral analysis (FFT) of temperature oscillations between 1950 and 1999 suggests a 5 yr cycle of temperature extremes, the disturbance-frequency recurrence appears to be between 10 and $15 \mathrm{yr}$ based on the size of acroporid colonies (100 to $150 \mathrm{~cm}$ maximum radius at the time of the 1996 overkill and assuming a growth rate of about $10 \mathrm{~cm} \mathrm{yr}^{-1}$ ) and reports of other severe mortality events in the literature (Shinn 1976, Coles \& Fadlallah 1991, Fadlallah et al. 1995, Holt Titgen 1982). This indicates that the interplay ENSO/IOZM is not the only mechanism driving SST anomalies in the Arabian Gulf, and it is likely that other factors need to coincide to cause extreme expressions of the SST anomalies. Also, elevated temperature is not the only factor required for coral bleaching. Brown et al. $(1994,2000,2002)$ demonstrated that coral bleaching seems to be caused by a combination of unusually high temperatures and oxidative stress caused by stronger than usual solar irradiation. Mumby et al. (2001) showed how Pacific corals did not bleach under heavy cloud cover despite anomalously elevated SST. 
We therefore suggest that bleaching-inducing combinations of unusual heat and solar irradiation occur approximately once every three ENSO events (therefore a period of 10 to $15 \mathrm{yr}$ ) in the studied area of the Arabian Gulf.

Although the exact mechanism behind the recurrence of episodic mass mortalities is not known, the observed spatial pattern of ample free space and relatively restricted areas of climax community can be explained by frequent disturbances that keep coral growth in check.

In conclusion, the combination of remote-sensing and ecological monitoring provides a powerful tool to evaluate the dynamics of complex ecosystems such as coral reefs in space and in time. The 2 methods each provide unique and intrinsically different information that can be merged. The spatial patterns revealed by remote-sensing can be directly interpreted as results of ecological patch-dynamics. The present study in the Arabian Gulf has shown that the proportion of dense to sparse coral growth and also the proportion of unsettled but suitable substratum obtained from the remotely sensed map, can be as important disturbance-indicators as temperature time-series and actual information about mortality events. Also the information about the absence of reef structure obtained from the digital elevation model was a valuable observation that could not as easily have been evaluated in its entire spatial dimension by divers. However, careful ground-truthing and control of hypotheses is necessary in order to avoid over-optimistic interpretations. With due diligence, however, the combination of remote-sensing and classical biological monitoring could provide a breakthrough in our understanding of ecological and spatial dynamics of such natural systems.

Acknowledgements. The authors are grateful for the continued backing of J. Kenter (VU) and R. Dodge (NSU). This study was supported by NOAA grant NA16OA1443 and Austrian Science Foundation (FWF) grant P13165-GEO. We thank J. Morrow and M. Holas (Biospherical Instruments) for the loan of the PRR600-610, H. van der Woerd and R. Pasterkamp (Institute for Environmental Studies/VU) for the PR650 and SD2000 spectroradiometers and M. Moerman (FEL-TNO) for the use of the sun photometer. The IKONOS image was provided via the NASA Scientific Data Purchase program. This is NCRI contribution 52.

\section{LITERATURE CITED}

Andréfouët S, Payri C (2000) Scaling-up carbon and carbonate metabolism of coral reefs using in situ data and remote sensing. Coral Reefs 19:259-269

Andréfouët S, Muller-Karger FE, Hochberg EJ, Hu C, Carder KL (2001) Change detection in shallow coral reef environments using Landsat 7 ETM+ data. Remote Sens Environ 78:150-162
Andréfouët $\mathrm{S}$, Kramer P, Torres-Pulliza D, Joyce KE and 12 others (2003) Multi-sites evaluation of IKONOS data for classification of tropical coral reef environments. Remote Sens Environ 88:128-143

Aronson RB, Precht WF, Macintyre IG, Murdoch, TJT (2000) Coral bleach-out in Belize. Nature 405:36

Braithwaite CJR, Montaggioni LF, Camoin GF, Dalmasso H, Dullo WC, Mangini A (2000) Origins and development of Holocene coral reefs: a revisited model based on reef boreholes in the Seychelles, Indian Ocean. Int J Earth Sci 89:431-445

Brown BE, Dunne RP, Scoffin TP, LeTissier MDA (1994) Solar damage in intertidal corals. Mar Ecol Prog Ser 105: 219-230

Brown BE, Dunne RP, Warner ME, Ambarsari I, Fitt WK, Gibb SW, Cummings DG (2000) Damage and recovery of Photosystem II during a manipulative field experiment on solar bleaching in the coral Goniastrea aspera. Mar Ecol Prog Ser 195:117-124

Brown BE, Downs CA, Dunne RP, Gibb SW (2002) Exploring the basis of thermotolerance in the reef coral Goniastrea aspera. Mar Ecol Prog Ser 242:119-129

Coles SL, Fadlallah YH (1991) Reef coral survival and mortality at low temperatures in the Arabian Gulf: new speciesspecific lower temperature limits. Coral Reefs 9:231-237

Colgan MW (1990) El Niño and the history of Eastern Pacific reef building. In: Glynn PW (ed) Global ecological consequences of the 1982-83 El Niño-Southern Oscillation. Elsevier Oceanogr Ser 52:183-229

Connell JH (1978) Diversity in tropical rain forests and coral reefs. Science 199:1302-1310

Downing N (1985) Coral reef communities in an extreme environment: the northwestern Arabian Gulf. Proc 5th Int Coral Reef Congr 6:343-348

Eakin CM (1996) Where have all the carbonates gone? A model comparison of calcium carbonate budgets before and after the 1982-83 El Niño at Uva Island in the eastern Pacific. Coral Reefs 15:109-119

Eakin CM (2001) A tale of two ENSO events: carbonate budgets and the influence of two warming disturbances and intervening variability, Uva Island, Panama. Bull Mar Sci 69:171-186

Eccles F, Tziperman E (2004) Nonlinear effects on ENSO's period. J Atmos Sci 61:474-482

Fadlallah YH, Allen KW, Estudillo RA (1995) Mortality of shallow reef corals in the western Arabian Gulf (Saudi Arabia). Bull Mar Sci 59:209-216

Fiedler PC (2002) Environmental change in the eastern tropical Pacific Ocean: review of ENSO and decadal variability. Mar Ecol Prog Ser 244:265-283

George JD, John DM (1999) High sea temperatures along the coast of Abu Dhabi (UAE), Arabian Gulf - their impact upon corals and macroalgae. Reef Encounter 25:21-23

George JD, John DM (2000) The coral reefs of Abu Dhabi, United Arab Emirates: past, present and future. Second Arab International Conference and Exhibition Environmental Biotechnology (Coastal Habitats), Abu Dhabi, UAE, 8-12 April 2000, Abstracts, p 39

George JD, John DM (2002) Is it curtains for coral reefs in the southern Arabian Gulf? In: Brooks S, Spencer T, Teleki K, Taylor M (eds) International Soc Reef Studies European Meeting, Cambridge, 4-7 September 2002, Abstracts, p 36

Glynn PW (1991) Coral reef bleaching in the 1980s and possible connections with global warming. Trends Ecol Evol 6:175-179

Glynn PW (1993) Coral bleaching: ecological perspectives. Coral Reefs 12:1-18 
Highsmith RC (1980) Geographic patterns of coral bioerosion: a productivity hypothesis. J Exp Mar Biol Ecol 46:177-196

Hoegh-Guldberg O (1999) Climate change, coral bleaching and the future of the world's coral reefs. Mar Freshw Res 50:839-866

Holt Titgen R (1982) The systematics and ecology of the decapods, and their zoogeographic relationship to the Arabian Gulf and the western Indian Ocean. PhD dissertation, Texas A \& M University, College Station, TX

Hubbard DK, Scaturo D (1985) Growth rates of seven species of Scleractinean corals from Cane Bay and Salt River, St. Croix, USVI. Bull Mar Sci 36:325-338

Ingle VK, Proakis JG (2000) Digital signal processing using Matlab. Brooks/Cole, Pacific Grove, CA

Kendall JJ Jr, Powell EN, Connor SJ, Bright TJ, Zastrow CE (1985) Effects of turbidity on calcification rate, protein concentration and the free amino acid pool of the coral Acropora cervicornis. Mar Biol 87:33-46

Kestin TS, Karoly DJ, Jano JI, Rayner NA (1998) Timefrequency variability of ENSO and stochastic simulations. J Climate 11:2258-2272

Kinsman DJJ (1964) Reef coral tolerance of high temperatures and salinities. Nature 202:1280-1282

Lambeck K (1996) Shoreline reconstructions for the Persian Gulf since the last glacial maximum. Earth Planet Sci Lett 142:43-57

Lenney PM, Woodcock CE, Collins JB, Hamdi H (1996) The status of agricultural lands in Egypt: the use of multitemporal NDVI features derived from Landsat. Remote Sens Environ 56:8-20

Lillesand TM, Kiefer RW (1994) Remote sensing and image interpretation, 3rd edn. John Wiley, New York

Loschnigg J, Webster PJ (2000) A coupled ocean-atmosphere system of SST modulation for the Indian Ocean. J Climate 13:3342-3360

Loschnigg J, Meehl GA, Webster PJ, Arblaster JM, Compo GP (2003) The Asian monsoon, the Tropospheric Biennial Oscillation, and the Indian Ocean Zonal Mode in the NCAR CSM. J Climate 16:1617-1642

Lough JM (2000) 1997-8: Unprecedented thermal stress to coral reefs? Geophys Res Lett 27:3901-3904

Lyons RG (1997) Understanding digital signal processing. Prentice Hall, Englewood Cliffs, NJ

Ma Z, Redmond RL (1995) Tau coefficients for accuracy assessment of classification of remote sensing data. Photogramm Eng Remote Sensing 61:435-439

Maeder J, Narumalani S, Rundquist DC, Perk RL, Schalles J, Hutchins K, Keck J (2002) Classifying and mapping general coral-reef structure using IKONOS data. Photogramm Eng Remote Sensing 68:1297-1305

Mumby PJ, Edwards AJ (2002) Mapping marine environments with IKONOS imagery: Enhanced spatial resolution can deliver great thematic accuracy. Remote Sens Environ 82:248-257

Mumby PJ, Harborne AR (1999) Development of a systematic classification scheme of marine habitats to facilitate regional management and the mapping of Caribbean coral reefs. Biol Conserv 88:155-163

Mumby PJ, Green EP, Edwards AJ, Clark CD (1997) Coral reef habitat mapping: How much detail can remote sensing provide? Mar Biol 130:193-202

Mumby PJ, Chisholm JRM, Edwards AJ, Andréfouët S, Jaubert J (2001) Cloudy weather may have saved Society Island reef corals during the 1998 ENSO event. Mar Ecol Prog Ser 222:209-216

Murty TS, El Sabh MI (1984) Storm tracks, storm surges and sea state in the Arabian Gulf and the Gulf of Oman.
In: Oceanographic modeling of the Kuwait Action Plan Region. UNESCO, Paris, p 5-20

Nasrallah HA, Nieplova E, Ramadan E (2004) Warm season extreme temperature events in Kuwait. J Arid Environ 56:357-371

Neumann AC, Macintyre IG (1985) Response to sealevel rise: keep-up, catch-up or give-up. Proc 5th Int Coral Reef Congr 3:105-110

Pasterkamp R, Peters SWM, van der Woerd H (2003) MERIS validation of geophysical ocean colour products: preliminary results for the Netherlands. In: Lacoste H (ed) Proceedings of the Envisat Validation Workshop. European Space Research Institute (ESRIN), Frascati

Peterson B (2001) IKONOS relative spectral response and radiometric calibration coefficients. Document number SE-REF-016, Revision A. Space Imaging, Thornton, CO

Philander SG (1990) El Niño, La Niña, and the Southern Oscillation. Academic Press, San Diego, CA

Purkis SJ (2004) Calibration of satellite images of reef environments. PhD dissertation, Vrije Universiteit Amsterdam, Amsterdam

Purkis SJ, Pasterkamp R (2004) Integrating in situ reef-top reflectance spectra with Landsat TM imagery to aid shallow-tropical benthic habitat mapping. Coral Reefs 23:5-20

Purkis SJ, Kenter JAM, Oikonomou EK, Robinson IS (2002) High-resolution ground verification, cluster analysis and optical model of reef substrate coverage on Landsat TM imagery (Red Sea, Egypt). Int J Remote Sens 23:1677-1698

Reynolds RW, Smith TM (1994) Improved global sea surface temperature analyses using optimum interpolation. J Climate 7:929-948

Riegl B (1999) Coral communities in a non-reef setting in the southern Arabian Gulf (Dubai, UAE): fauna and community structure in response to recurrent mass mortality. Coral Reefs 18:63-73

Riegl B (2001) Inhibition of reef framework by frequent disturbance: examples from the Arabian Gulf, South Africa, and the Cayman Islands. Palaeogeogr Palaeoclimatol Palaeoecol 175:79-101

Riegl B (2002) Effects of the 1996 and 1998 sea surface temperature anomalies on corals, fish and coral diseases in the Arabian Gulf (Dubai, UAE). Mar Biol 140:29-40

Riegl B, Branch GM (1995) Effects of sediments on the energy budgets of four scleractinian (Bourne 1900) and five alcyonacean (Lamouroux 1816) corals. J Exp Mar Biol Ecol 186:259-275

Riegl B, Piller WE (2000) Biostromal coral facies - a Miocene example from the Leitha limestone (Austria) and its actualistic interpretation. Palaios 15:399-413

Riegl B, Heine C, Branch GM (1996) Function of funnelshaped coral growth in a high-sedimentation environment. Mar Ecol Prog Ser 145:87-93

Riegl B, Korrubel JL, Martin C (2000) Mapping and monitoring of coral communities and their spatial patterns using a surface-based video method from a vessel. Bull Mar Sci 69:869-880

Roelfsema CM, Phinn SR, Dennison WC (2002) Spatial distribution of benthic microalgae on coral reefs determined by remote sensing. Coral Reefs 21:264-274

Schott JR, Salvaggio C, Volchok J (1988) Radiometric scene normalization using pseudoinvariant features. Remote Sens Environ 26:1-14

Sheppard CRC, Loughland R (2002) Coral mortality and recovery in response to increasing temperature in the southern Arabian Gulf. Aquatic Ecosystem Health Manag 5:395-402 
Sheppard CRC, Price ARG, Roberts CM (1992) Marine ecology of the Arabian region: patterns and processes in extreme tropical environments. Academic Press, London

Sheppard CRC, Wilson SC, Salm RV, Dixon D (2000) Reefs and coral communities of the Arabian Gulf and Arabian Sea. In: McClanahan TR, Sheppard CRC, Obura DO (eds) Coral reefs of the Indian Ocean. Their ecology and conservation. Oxford University Press, Oxford, p 257-293

Shinn EA (1969) Submarine lithification of Holocene carbonate sediments in the Persian Gulf. Sedimentology 12: 109-144

Shinn EA (1976) Coral recovery in Florida and the Persian Gulf. Environ Geol 1:241-254

Spencer T, Teleki KA, Bradshaw C, Spalding MD (2000) Coral bleaching in the southern Seychelles during the 1997-1998 Indian Ocean warm event. Mar Pollut Bull 40:569-586

van Woesik R (2004) Comment on 'Coral reef death during the 1997 Indian Ocean dipole linked to Indonesian wildfires'. Science 303:1296-1297

van Woesik R, Done TJ (1997) Coral communities and reef

Editorial responsibility: Otto Kinne (Editor-in-Chief),

Oldendorf/Luhe, Germany growth in the southern Great Barrier Reef. Coral Reefs 16: 103-115

Wang B, Wang Y (1996) Temporal structure of the Southern Oscillation as revealed by waveform and wavelet analysis. J Climate 9:1586-1598

Wellington GM, Glynn PW, Srong AE, Nauarrete SA, Wieters E, Hubbard D (2001) Crisis on coral reefs linked to climate change. EOS Trans Am Geophys Uni 82:1-7

Wilkinson C (ed) (2000) Status of coral reefs of the world: 2000. Australian Institute of Marine Science, Townsville

Wilson JD (1992) A comparison of procedures for classifying remotely-sensed data using simulated data sets. Int J Remote Sens 13:365-386

Wolter K, Timlin MS (1993) Monitoring ENSO in COADS with a seasonally adjusted principal component index. Proceedings of 17 th Climate Diagnostics Workshop, Norman, OK, NOAA/N MC/CAC, NSSL, Oklahoma Climate Survey, CIMMS and the School of Meteorology University of Oklahoma, March 1993, NOAA 52-57

Wolter K, Timlin MS (1998) Measuring the strength of ENSO-How does 1997/98 rank? Weather 53:315-324

Submitted: November 10, 2003; Accepted: August 24, 2004 Proofs received from author(s): February 7, 2005 